\title{
The Effect of Green Roof on Energy Consumption of Two Storey Air-Conditioned Residential Buildings In Desert Climates
}

\author{
KHALED EL-DEEB \\ Department of Architecture, Faculty of Fine Arts, Alexandria University, Egypt.
}

\begin{abstract}
Green roofs serve for multiple functions in relevance to the environment, sustainability, aesthetics, visual comfort and energy-efficiency. In hot climates, a green roof can have a crucial role in decreasing cooling loads through thermal mass and evaporative cooling through plant transpiration. It can be implemented on new or existing building constructions.
\end{abstract}

Currently, a large building stock exists and many new settlements are either newly-built or under construction in Egypt, of which an increasing portion is air-conditioned. The presence of recyclable waste water that can be used for irrigation increases the potential of using green roofs especially in countries with high population. This potential indicated the need to quantitatively explore the effect of green roof parameters on energy consumption in this type of air-conditioned residential buildings located in desert climates.

This study investigated the effect of different green roof parameters on energy consumption of two-storey residential buildings located in desert climates. These included leaf area index, soil thickness, soil conductivity and thermal insulation.

A two-storey residential building was modelled and simulated for energy performance using EnergyPlus. Green roof parameters were tested for their effect on energy consumption. Results were compared to a base case of standard un-insulated roof and to alternatives of roof insulation. Results showed that in desert cities, the green roof achieved savings of up to $30 \%$ in Kargah city, $28 \%$ in Cairo and $24 \%$ in Alexandria. Savings achieved by a green roof in desert cities were more than those achieved by thermal insulation. For comparison a city with a temperate climate, Berlin, was also tested, in which thermal insulation proved to be of more savings than a green roof.

Keywords: Green roof; residential buildings; air-conditioned; energy consumption; building performance simulation.

\section{INTRODUCTION}

Green roofs serve for multiple functions in relevance to the environment, sustainability, aesthetics, visual comfort and energy-efficiency. In hot climates, a green roof can have a crucial role in decreasing cooling loads through thermal mass and evaporative cooling 
through plant transpiration. It can be implemented on new or existing building constructions.

Currently, a large building stock exists and many new settlements are either newly-built or under construction in Egypt and other Arab countries, of which an increasing portion is air-conditioned. The presence of recyclable waste water that can be used for irrigation increases the potential of using green roofs especially in countries with high population. This potential indicated the need to quantitatively explore the effect of green roof parameters on energy consumption in this type of air-conditioned residential buildings located in desert climates.

A number of previous studies addressed the effect of green roofs on the urban and building levels. On the urban level, green roofs was addressed as a mitigation measure for urban heat island (UHI) effect [1]. Shinzato and Duarte (2012) studied the cooling effect of vegetation on the urban scale using LAls 1,3and 5 showing a surface temperature difference between green area and street of 5,10 and $14.7^{\circ} \mathrm{C}$ for LAl cases respectively [2]. Lilliana and Jim studied UHI effect in subtropical climate, finding that the effect of green roof on microclimate exceeds the roof top to the surrounding streets [3]. On the building level, the green roof effect on energy consumption in buildings was addressed in a number of studies. For example, Kamel et al. studied the effect of GR soil conductivity and thickness on energy consumption at a fixed leaf-area index (LAI) under the climate of Cairo, Egypt [4], energy savings of 15-32\% were achieved. Mukherjee et al. studied the effect of LAI, soil thickness and thermal insulation layers for different climates in the United States of America [5]. Niachou et al studied the thermal and energy performance of green roofs through physical measurements of indoor and outdoor temperatures [6]. For a commercial building green roof, Zhao et el compared between the roof materials thermal performance by exploring different plant and substrate types [7]. Sailor et al. developed a green roof module to be used in energy simulation tools, that was first included by the U.S. Department of Energy in the EnergyPlus tool in April 2007 [8,9]. The updated version of this simulation tool was used for performance simulation in this study.

Previous studies indicated that the impact of green roofs on energy consumption of airconditioned residential buildings located in desert climates needs more investigation.

\section{OBJECTIVES}

This research aims at exploring the effect of green roof parameters on energy consumption of two-storey residential buildings located in desert climates. This includes the following parameters:

- Leaf-Area Index (LAI).

LAI is the projected leaf area per unit area of soil surface. It is a dimensionless value. Simulation software accepts values from 0.001 to 5 . Figure 1 shows sample of measured LAI values of different plants [10] 
Figure (1) Sample of measured LAI values of different plants.

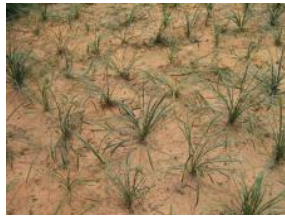

LAI: nearly zero

Too sparse to be measured

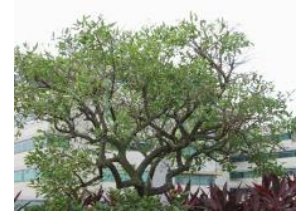

LAI: 1.69

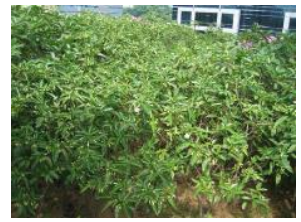

LAI: 3.07

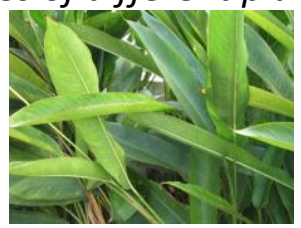

LAI: 5.28

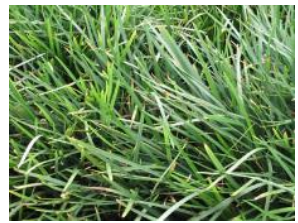

LAI: 6.66

Source: reproduced from Chen Yu, (2006) [10]

- $\quad$ Soil Thickness (ST).

- Soil Conductivity (SC).

- Thermal Insulation (TI).

\section{METHODOLOGY}

A two-storey residential building was modelled in DesignBuilder software tool and simulated for energy consumption using EnergyPlus. The building form was a square of $10 \mathrm{~m} \times 10 \mathrm{~m}$ footprint, where each floor was considered as a single zone with no internal partitions. A residential occupancy schedule was applied. Simulated building parameters are described in Table 1.

Table (1) Simulated building parameters.

\begin{tabular}{|l|l|ll|}
\hline \multicolumn{4}{|c|}{ BUILDING PARAMETERS } \\
\hline DIMENSIONS & $10 \mathrm{X} 10 \mathrm{~m}$ & HVAC & Setpoint \\
\hline No. of Floors & 2 & Cooling & 23 \\
\hline No. of people & $0.04 / \mathrm{m} 2$ & Heating & 21 \\
\hline Activity & Residential & Type & Split \\
\hline LIGHTING & Type & Fluorescent & Suspended \\
Daylighting control & Illuminance: & $\begin{array}{l}\text { Dimming: } \\
\text { Linear/off }\end{array}$ & $\begin{array}{l}\text { Sensor Height: } \\
0.8 \mathrm{~m}\end{array}$ \\
\hline CONSTRUCTION & \multicolumn{3}{|l|}{} \\
Wall & 20cm concrete block + 2cm cement plaster \\
Roof & variable: Standard / Green Roof \\
\hline Windows & Double-glazed clear & WWR: \\
\hline CITIES & Cairo, Khargah, Alexandria, Berlin \\
\hline
\end{tabular}

The modelled building with a standard un-insulated roof was considered as the base case. The standard roof was also tested for thermal insulation values of 5, 10, 15 and $20 \mathrm{~cm}$ in order to compare the savings achieved by a green roof to that of insulated standard roofs.

Then, a green roof was introduced, including a root barrier layer and layers for drainage, and water proofing. The green roof top layer included the growing medium (soil) and the plants. The cases of roof layers are shown in Figure 2. Alternatives and combinations of green roof parameters were tested for a number of values as in Table 2. 
Table (2) Tested standard and green roof parameters combinations.

\begin{tabular}{|c|c|c|c|c|c|}
\hline \multirow{2}{*}{\multicolumn{2}{|c|}{$\begin{array}{l}\text { STANDARD ROOF } \\
\text { Thermal Insulation (TI) }\end{array}$}} & \multicolumn{4}{|c|}{ TESTED AT: } \\
\hline & & \multicolumn{2}{|c|}{$0 \mathrm{~cm}$} & \multicolumn{2}{|c|}{ [ BASE CASE ] } \\
\hline & & \multicolumn{4}{|c|}{$5,10,15,20 \mathrm{~cm}$} \\
\hline \multirow{2}{*}{$\begin{array}{l}\text { GREEN ROOF } \\
\text { PARAMETERS }\end{array}$} & \multirow{2}{*}{$\begin{array}{l}\text { TESTED } \\
\text { VALUES }\end{array}$} & \multicolumn{4}{|c|}{ TESTED AT: } \\
\hline & & LAI & ST & SC & TI \\
\hline $\begin{array}{l}\text { Leaf Area Index } \\
\text { (LAI) }\end{array}$ & $\begin{array}{l}1 \\
2 \\
3 \\
4 \\
5\end{array}$ & & 10 & 0.3 & 0 \\
\hline $\begin{array}{l}\text { Soil Thickness } \\
\text { (ST) }\end{array}$ & $\begin{array}{l}10 \\
30< \\
50<\end{array}$ & $\begin{array}{r}1 \\
\times \\
3 \\
\times \\
5\end{array}$ & & 0.3 & 0 \\
\hline $\begin{array}{l}\text { Soil Conductivity } \\
\text { (SC) }\end{array}$ & $\begin{array}{l}0.3 \\
0.6 \\
0.9\end{array}$ & $\begin{array}{l}1 \\
=5\end{array}$ & $\begin{array}{r}10 \\
<5\end{array}$ & & 0 \\
\hline $\begin{array}{l}\text { Thermal Insulation } \\
\text { (TI) }\end{array}$ & $\begin{array}{l}0 \\
5<\end{array}$ & $\begin{array}{r}1 \\
3 \\
5\end{array}$ & 10 & 0.3 & \\
\hline
\end{tabular}

Figure (2) Standard roof layers, green roof layers and the building model.

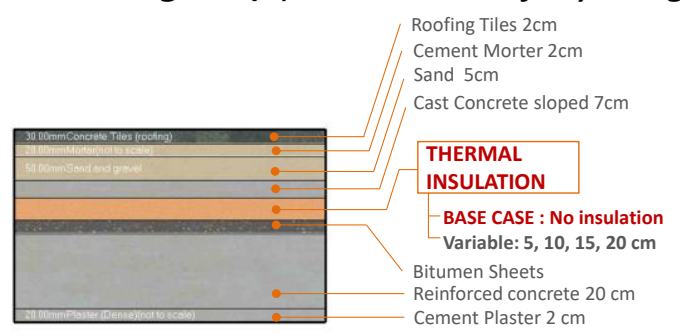

STANDARD ROOF

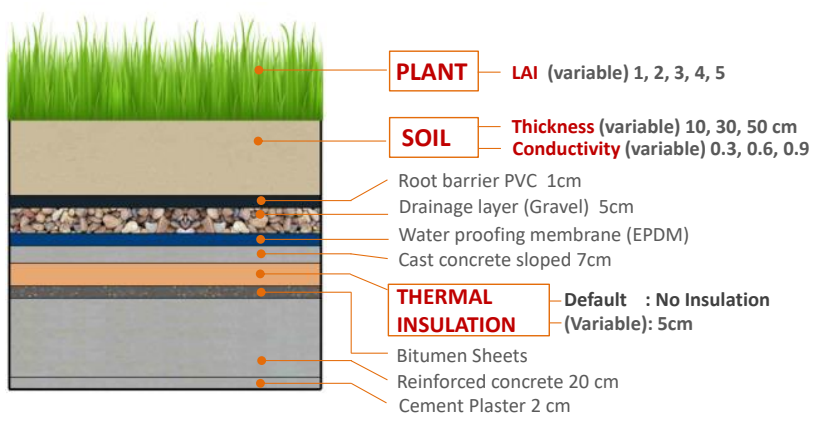

GREEN ROOF

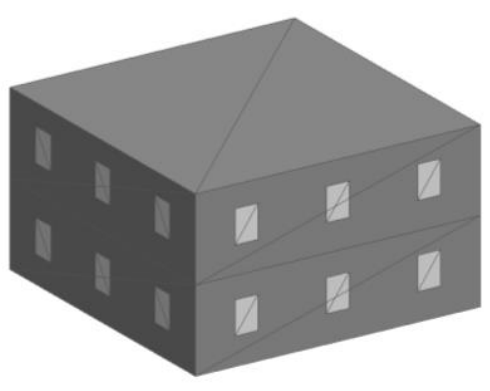

Building Model

Performance simulations took place for three Egyptian cities classified by Köppen-Gieger climate classification as desert climates: Alexandria, Cairo and Khargah [11]. Despite this, there are some differences in mean daily temperatures between them, Figure 3. For comparison reason, simulations were also performed for a city with Temperate climate: Berlin, Germany. 
Figure(3) Mean daily maximum and minimum temperatures in tested cities.

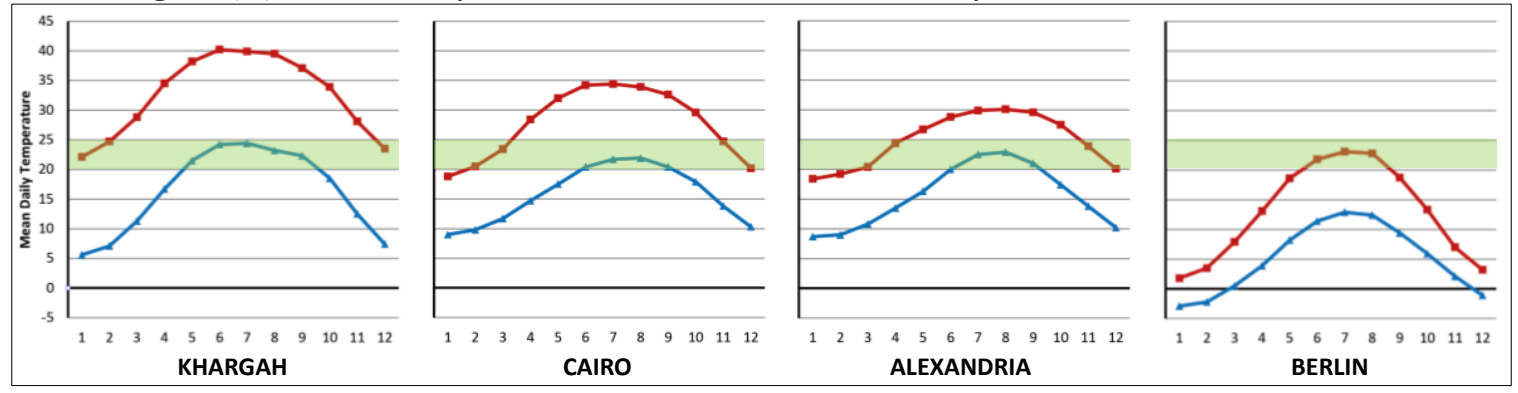

\section{LIMITATIONS}

The same base case parameters were used for all tested cities including Berlin. These parameters are not the common practice in that city; however, they were used only for comparison purpose under a different climate.

\section{RESULTS}

Results for the base case standard roof and those of the green roof can be shown as follows:

\section{The Base Case:}

Simulation results for the base case building showed that EUI differed across the cities in response to their climates: Khargah was the highest in EUI across the three desert cities followed by Cairo, then Alexandria, Figure 4. The three were dominated by cooling loads, while some heating loads were found that were of minimum values in Khargah, and highest in Alexandria. Annual EUI values were 199, 139 and $107 \mathrm{kwhr} / \mathrm{m} 2$ for Khargah, Cairo and Alexandria respectively. On the contrary, Berlin was dominated by heating loads, while a small value of cooling load was needed in summer. Values for lighting loads ranged from 17.3 to $18.8 \mathrm{kwhr} / \mathrm{m} 2$ in desert cities while reached $22.2 \mathrm{kwhr} / \mathrm{m} 2$ in Berlin due to the cloudy sky conditions.

Figure (4) Base case EUI values in tested cities.

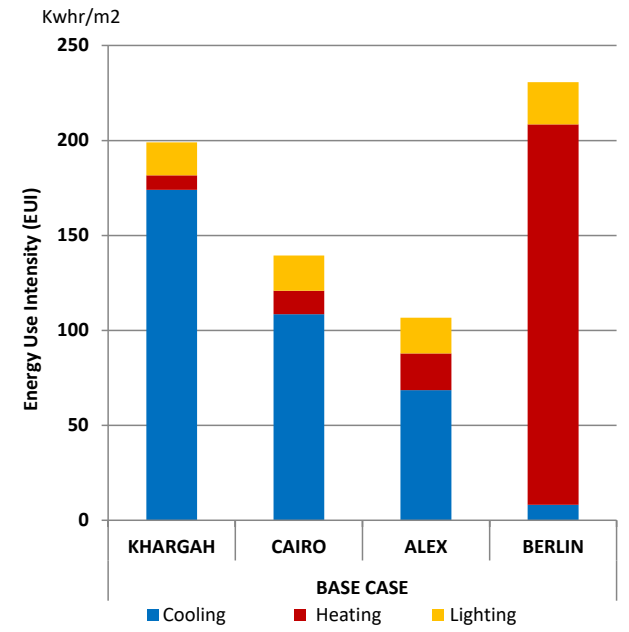




\section{Thermal Insulation of Standard Roof}

Thermal insulation layer alternatives of different thicknesses ranging from 2.5 to $20 \mathrm{~cm}$ were applied to the model with a standard roof. Results showed that savings increased by increasing the thickness of the insulation layer. However, the largest portion of the savings was achieved at smaller thicknesses. For example, in Khargah, at $5 \mathrm{~cm}$ insulation thickness, $20 \%$ savings were achieved, while at $10 \mathrm{~cm}$, the result was only $3 \%$ additional savings, and another $2 \%$ resulted at $15 \mathrm{~cm}$ and $1 \%$ at $20 \mathrm{~cm}$. This indicated that the first $5 \mathrm{~cm}$ thickness resulted in about four times the savings achieved by the following $15 \mathrm{~cm}$ of thickness. Figure 5 showed a similarity in the savings patterns in the four cities. Khargah and Cairo results were nearly coinciding. The savings achieved by $20 \mathrm{~cm}$ of standard roof thermal insulation reached $26 \%$ in Khargah and Cairo, and about $22 \%$ in Alexandria and Berlin. These values were used for comparison to those resulting from the green roof cases.

Figure (5) Percentage of energy savings achieved by alternatives of thermal insulation thicknesses of a standard roof.

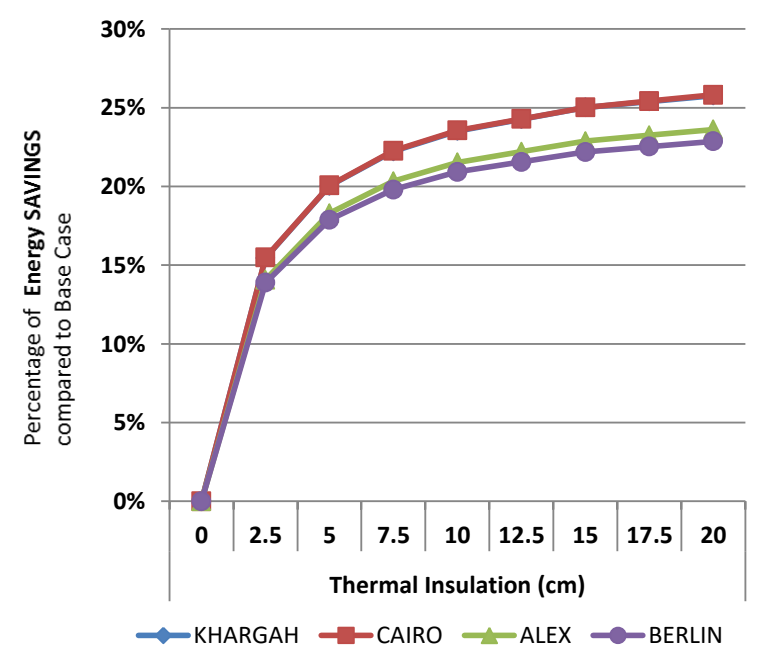

\section{GREEN ROOF}

Simulations performed for the green roof showed a high potential for energy savings in desert cities compared to both standard un-insulated and insulated roof cases. The values of green roof energy savings were influenced by the tested parameters. The effect of these parameters can be described as follows:

\section{Leaf Area Index}

LAl values ranging from 1 to 5 were simulated with constant parameters : soil thickness $10 \mathrm{~cm}$ and soil conductivity 0.3 . Results in desert cities showed an increase in energy savings occurred as the LAl increased. Additional saving of $6 \%$ in Alexandria, and $8 \%$ in Cairo and Khargah were achieved by increasing the LAl value from 1 to 5 . In Berlin, the effect of LAI on energy consumption was insignificant and nearly no changes in savings occurred. These results reflected the positive shading effect that occurred through 
dense plantation in desert cities, while that was not of significance in a heating dominated temperate city, Berlin, Figure 6.

Figure (6) Percentage of energy savings achieved by alternatives LAls.

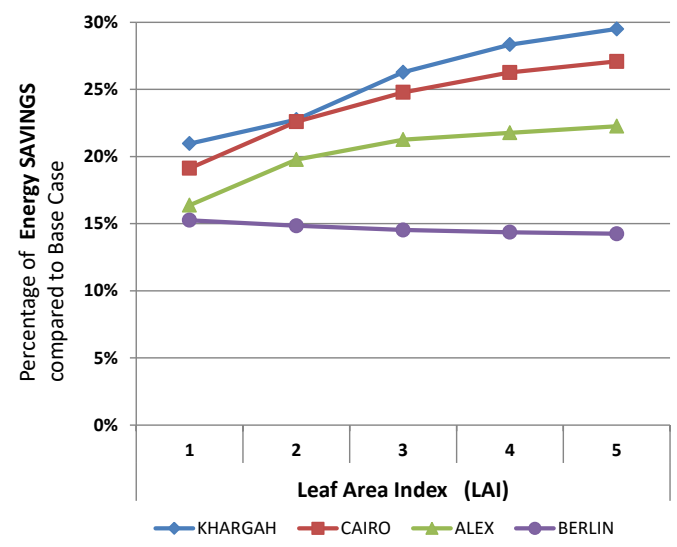

\section{Soil Thickness, Thermal Insulation and Leaf Area Index}

Three values of soil thicknesses $(10,30,50 \mathrm{~cm})$ were tested at Leaf area index $(1,3,5)$ in the four cities. Results showed that the increase in LAl - for each soil thickness - led to an increase in the energy savings in all desert cities, while had a negligible effect in Berlin, Figure 7.

Results also showed that the difference between the values of energy savings achieved by a green roof at $10 \mathrm{~cm}$ and at $50 \mathrm{~cm}$ soil thickness ranged from 5 to $6 \%$ in all cities at LAI 1. These values decreased to only 1 to $2 \%$ in desert cities at LAI 3 , and to nearly $0 \%$ in Khargah and Cairo at LAI 5, while remained $2 \%$ in Alexandria. On the other hand, in Berlin the difference was $6 \%$ in all LAI values. This indicates that, in desert cities, the soil thickness has a significant effect only at low LAl value, while at high LAI, it becomes either of no effect or insignificant effect. This can be explained as the shading effect of plants at high LAl served in reducing the roof's surface temperature by blocking a larger portion of direct solar radiation than in low LAI, minimizing the temperature difference between the indoor and outdoor and thus minimizing heat transfer by conduction, and consequently minimizing the effect of soil thickness. This was useful in desert climates, where a large amount of solar radiation is found, while in the temperate climate of Berlin the shading effect either led to insignificant or decreased amounts of savings.

Compared to the cases of standard roof insulation, the green roof at a high LAI and 10 or $30 \mathrm{~cm}$ of soil thickness exceeded the savings achieved by $20 \mathrm{~cm}$ thermal insulation of a standard roof in Khargah and Cairo, and was of nearly a similar value in Alexandria. Compared to the commonly used $5 \mathrm{~cm}$ insulation thickness, nearly all green roof cases resulted in significant additional savings that reached 9\% in Khargah and Cairo, and 6\% in Alexandria. Only the GR cases of LAI 1 and soil thickness $10 \mathrm{~cm}$ were of less yet close savings to that of the standard roof with $5 \mathrm{~cm}$ thermal insulation. In Berlin, thermal insulation generally showed more savings than the green roof. The standard roof with 
$5 \mathrm{~cm}$ insulation resulted in $3 \%$ more savings than $G R$ of $10 \mathrm{~cm}$ soil thickness, while equivalent savings of a GR with $50 \mathrm{~cm}$ soil thickness and LAI 5 was achieved b only $10 \mathrm{~cm}$ of thermal insulation.

Figure (7) Effect LAI and Soil thickness, compared to base case and standard roof insulation
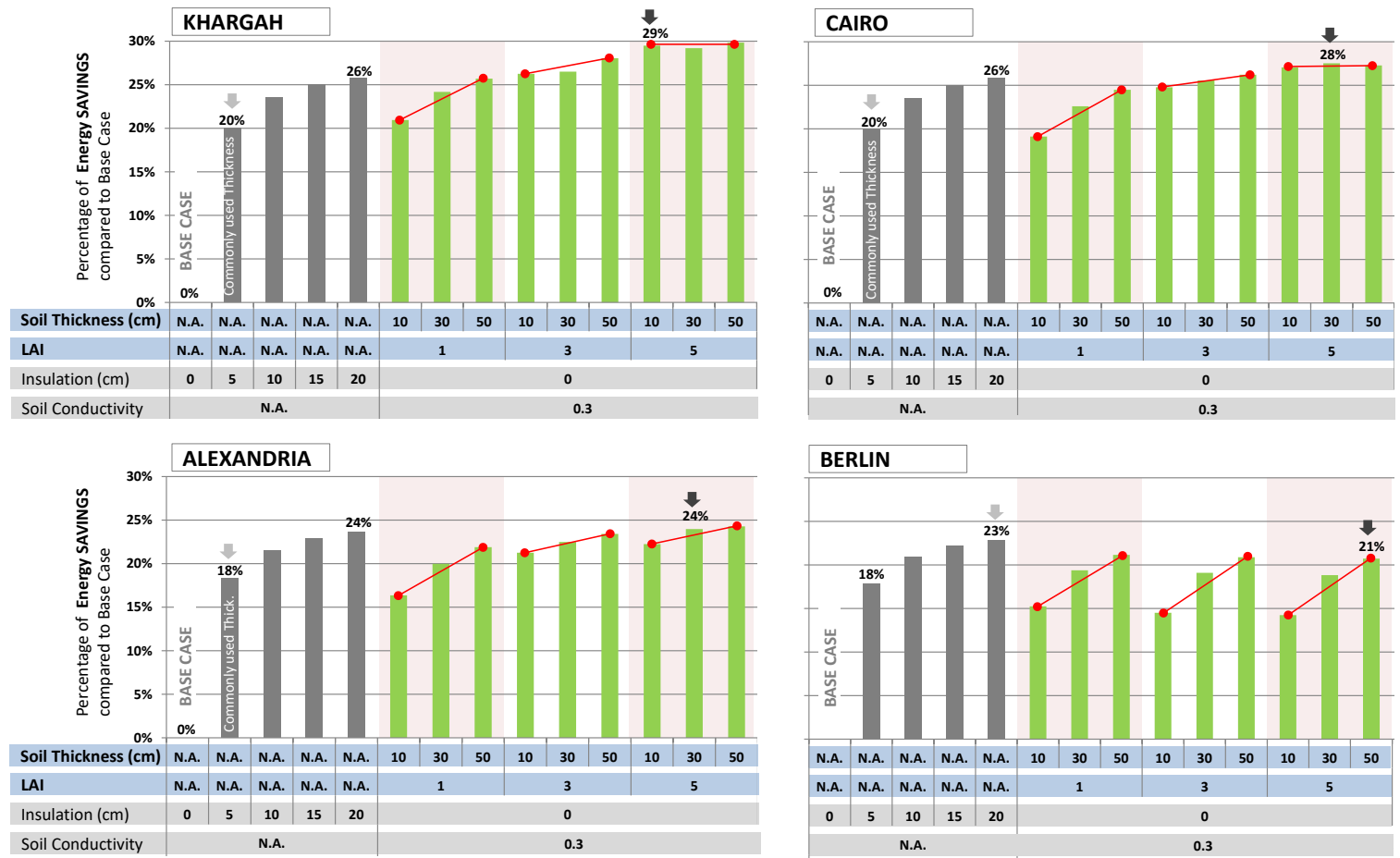

\section{Soil Conductivity}

Soil conductivity values of $0.3,0.6$ and 0.9 were tested at LAls 1 and 5 , and at soil thicknesses 10 and $50 \mathrm{~cm}$.

In the desert cities, the difference in Soil Conductivity (0.3-0.9) resulted in $2 \%$ difference in energy savings at LAI 1 and soil thickness $10 \mathrm{~cm}$. By the increase in soil thickness to $50 \mathrm{~cm}$ at the same LAI 1, this value showed a slight increase to range from 3 to $4 \%$ indicating a slightly higher effect of soil conductivity at larger soil thickness and low LAl; the lower the conductivity the higher the savings. However, at the high LAI 5, the effect of soil conductivity was nearly negligible in both soil thicknesses of $10 \mathrm{~cm}$ and $50 \mathrm{~cm}$, indicating that the shading effect at high LAI minimizes the effect of soil conductivity as well as that of soil thickness. On the other hand, in Berlin, the effect of conductivity did not change by changing LAI, while slightly increased by the increase in soil thickness. See Figure 8 . 
Figure (8) Effect of soil conductivity at LAls 1 and 5 and at soil thicknesses 10 and $50 \mathrm{~cm}$.
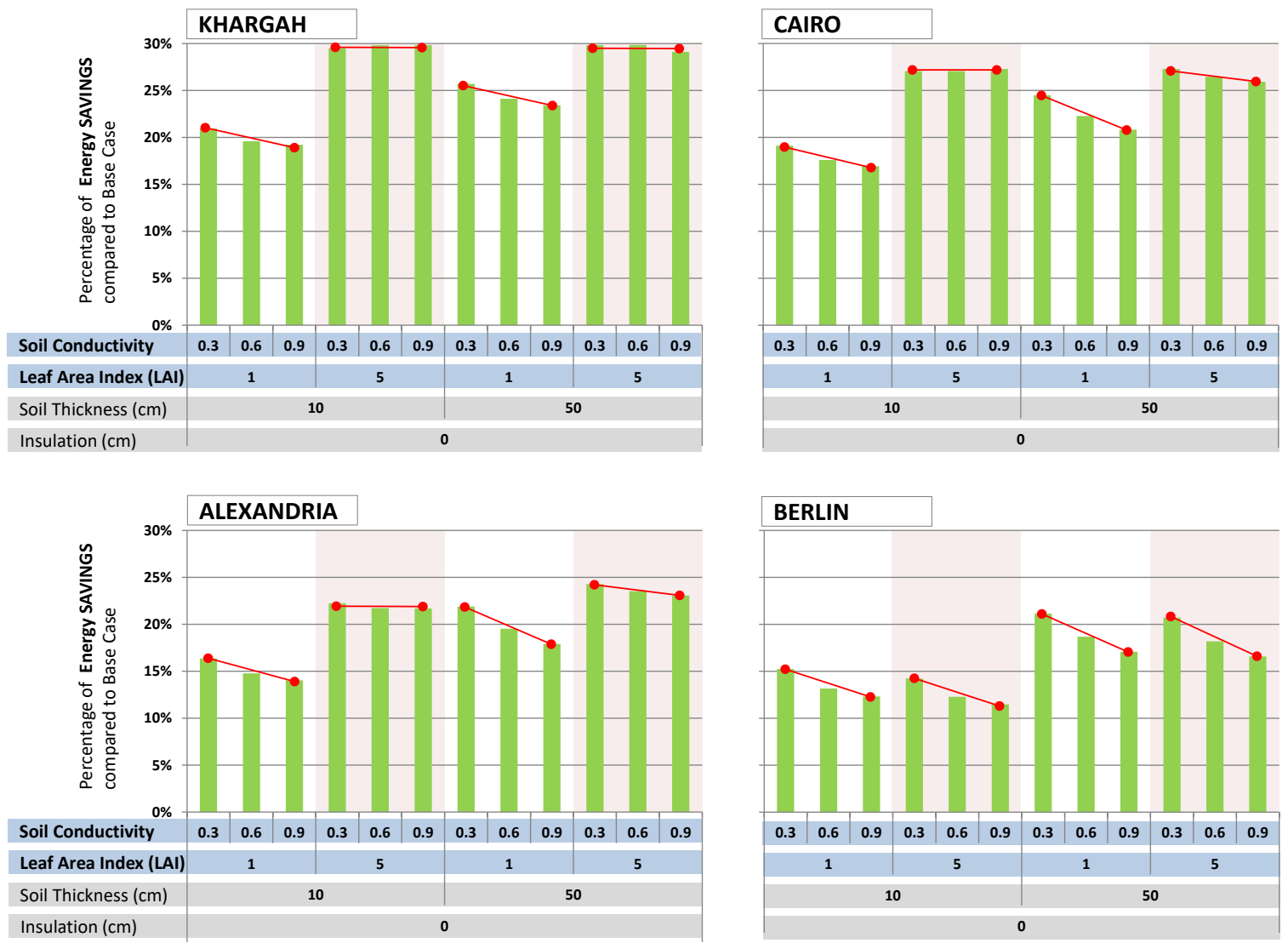

\section{Insulated Green Roof}

A layer of $5 \mathrm{~cm}$ thermal insulation was added to a $G R$ of a soil thickness $10 \mathrm{~cm}$ and conductivity 0.3 , in cases of LAI 1,3 and 5 . The savings achieved by the insulated GR was compared to that of the un-insulated one, Figure 9.

Figure (9) Effect of adding a $5 \mathrm{~cm}$ thermal insulation layer to the green roof compared to the un-insulated case at LAI 1-3-5.
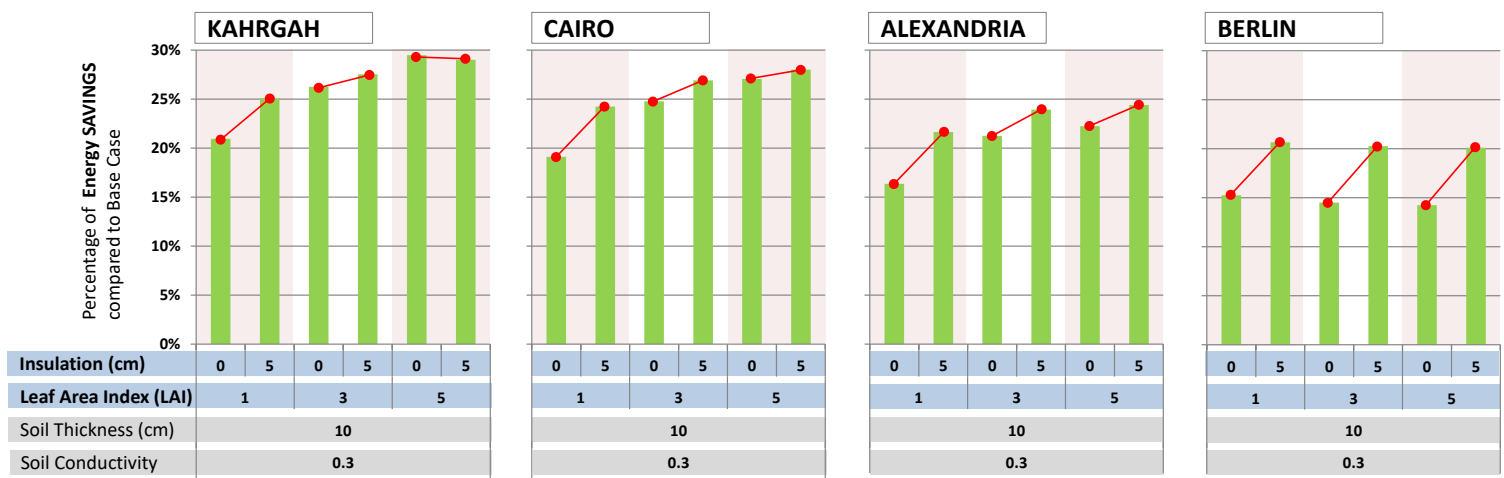

The insulated GR showed more savings, up to 4,5and 6\% in Khargah, Cairo and Alexandria, respectively at LAI 1 . These values decreased to $1.5-3 \%$ at LAI 3 , and to $0-2 \%$ 
at LAI 5 in these desert cities, showing that the amount of additional savings provided by insulating the green roof were of less significance at LAls 3 and 5 . In Berlin, this value was significant even at high LAls - nearly $6 \%$ in all LAl cases- as minimizing heat loss was of a more significant effect than that of the shading effect of the green roof.

\section{CONCLUSIONS}

In tested cities, the following points can be concluded.

- A densely-planted green roof of medium soil thickness showed a high potential for energy savings that reached $24-29 \%$ in tested desert cities, and $19 \%$ in Berlin when compared to a standard un-insulated roof.

- Compared to a standard roof with $5 \mathrm{~cm}$ thermal insulation, the stated green roof achieved 6-9\% more savings in desert cities, while was of nearly the same amount as the former one in Berlin.

- In desert cities, the savings achieved by the green roof exceeded those achieved by thermal insulation of a standard roof even when compared to the case where the insulation thickness reached $20 \mathrm{~cm}$. On the other hand, in Berlin, it was of about $5 \%$ less savings than that case of insulation.

- In general, the green roof was more efficient than thermal insulation in tested desert cities, while despite achieving significant savings, it was less efficient than thermal insulation in Berlin.

- Leaf Area Index is a key parameter in desert cities. The increase in LAI leads to an increase in energy savings, and to dampening the effect of soil thickness, conductivity and thermal insulation. It was not of a significant effect in Berlin. This reflected the importance of solar shading in desert climates, rather than in the temperate climate, where annual shading can result in a negative effect in the heating seasons.

- By increasing LAI value from 1 to 5, additional energy savings of $9 \%, 8 \%$ and $6 \%$ were achieved in Khargah, Cairo and Alexandria respectively, indicating that the benefit increased in hotter cities.

- Soil thickness has an insulative effect. Increasing soil thickness lead to increasing energy savings at LAI 1 by additional $5-6 \%$ in desert climates. However, the increase in thickness did not achieve significant savings at higher LAls (3-5), as the shading effect of the dense plantation helped minimize heat gains from direct solar radiation, thus decreasing surface temperature, and heat transfer by conduction.

- Soil thickness remained of importance even at high LAI in the temperate climate of Berlin.

- In desert cities, soil conductivity had a negligible effect on energy savings at the high LAI 5, while had a small effect at the small LAI 1. At the latter case, that effect was $2-3 \%$ at small soil thickness $(10 \mathrm{~cm})$ and $3-4 \%$ at high thickness $(50 \mathrm{~cm})$. In Berlin, the difference in conductivity resulted in $3 \%$ difference in savings in all LAl cases. In these case savings decreased by the increase in soil conductivity. 
- Adding a $5 \mathrm{~cm}$ layer of thermal insulation to a green roof was beneficial in desert cities only at the low LAI 1 value, while in the temperate climate it was also of benefit at higher LAls. It achieved nearly $5 \%$ additional savings at LAI 1 in all cities, while at LAls 3,5 these additional savings decreased and were insignificant in desert cities but stayed of nearly the same significance in Berlin.

- In Egypt, a green roof with LAI 5, soil conductivity 0.3 and soil thicknesses $10 \mathrm{~cm}$ in Khargah and Cairo and $30 \mathrm{~cm}$ in Alexandria can be recommended as this achieved high savings, even when compared to standard roof insulation $5 \mathrm{~cm}$.

\section{FUTURE RESEARCH}

Further research is needed to assess the impact of green roofs on energy consumption in multi-storey buildings of different height proportions, and on building types other than residential such as office buildings, where internal loads are higher than that in the former type.

\section{REFERENCES}

1. Ardeshir Mahdavi, Kristina Kiesel, Milena Vuckovic, A framework for evaluation of urban heat island mitigation measures, Proceedings of Sustainable Building Conference SB13: Implementing sustainability - Barriers and chances, Munich, 24-26 April 2013; p 254261.

2. Paula Shinzato and Denise Duarte, 2012, Microclimatic Effect of Vegetation for Different Leaf Area Index - LAl, proceedings of the international conference on passive low-energy Architecture PLEA2012 - 28th Conference, Opportunities, Limits \& Needs Towards an environmentally responsible architecture Lima, Perú 7-9 November 2012.

3. Lilliana L.H. Peng and C.Y. Jim, Green-Roof Effects on Neighborhood Microclimate and Human Thermal Sensation, Energies, (6) 2013 , p598-618.

4. Basil Kamel, Sherine Wahba, Khaled Nassar and Ahmed Abdelsalam, Effectiveness of Green-Roof on Reducing Energy Consumption through Simulation program for a Residential Building: Cairo, Egypt , proceedings of Construction Research Congress 2012; p1740-1749.

5. Sananda Mukherjee1, Pablo La Roche2, Kyle Konis1, Joon Ho Choi1, 2013, Thermal Performance of Green Roofs: A Parametric Study through Energy Modelling in Different Climates, proceedings of the international conference on passive low-energy Architecture PLEA2013 - 29th Conference, Sustainable Architecture for a Renewable Future, Munich, Germany 10-12 September 2013.

6. A Niachou, K Papakonstantinou, M Santamouris, A Tsangrassoulis, G Mihalakakou, Analysis of the green roof thermal properties and investigation of its energy performance, Energy and Buildings, 33 (7) 2001, p 719-729.

7. Mingji Zhao, Paulo Cesar Tabares-Valesco, Jelena Srebric, Sridhar Komarneni, Comparison of green roof plants and substrates based on simulated green roof thermal performance with measuredmaterial properties, proceedings of BS2013:13th Conference of International Building Performance Simulation Association, Chambéry, France, August 26-28.

8. David Sailor, Graig Spolek, David Ervin, Developing design tools for estimating the energy and water performance of green roofs - annual report, Portland State University, 2008. 
9. Sailor, D.J.,A Green Roof Model for Building Energy Simulation Programs, Energy and Buildings 40 (8), 1466-1478, 2008.

10. Yu, C., (2006), The intervention of plants in the conflict between buildings and climate a case study in Singapore, PhD thesis, Department of Building, National University of Singapore.

11. Kottek M. et al. (2006). World Map of the Köppen-Gieger Climate Classification Updated. MeterologischeZeitschrift; 15(3): 259-63.

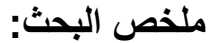

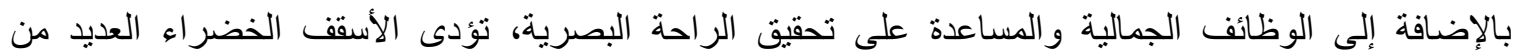

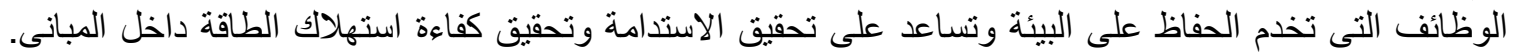

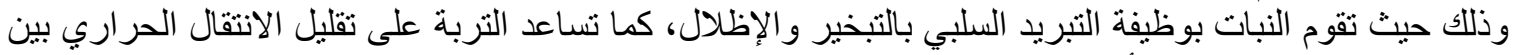

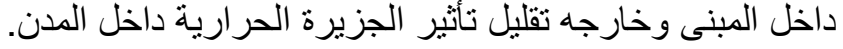

فى الوقت الحالى قى مصر يوجد عدد هائل من المبانى القائمة وعدد كبير من التجمعات السكنية و المدن الجديدة إما

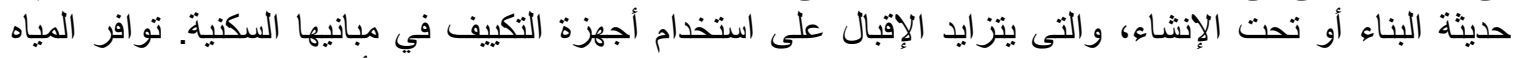

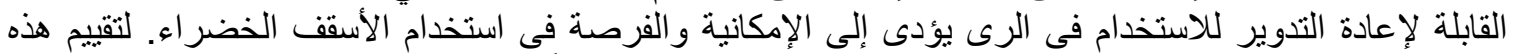

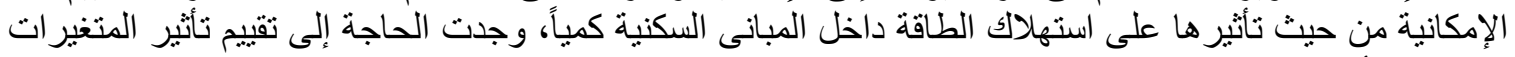
المختلفة للأسقف الخضر اءء على استهلاك الطاقة بالمبانى السكنية المكيفة الو اقعة فى المناخ الصحاني الصحر اوى.

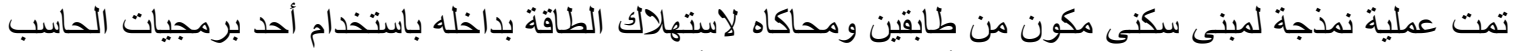

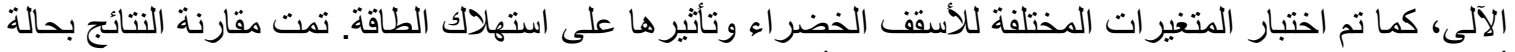

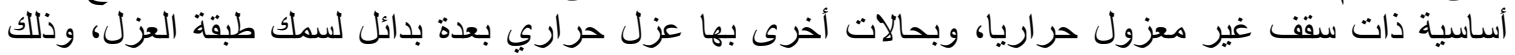

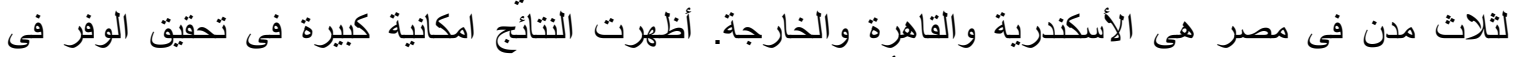

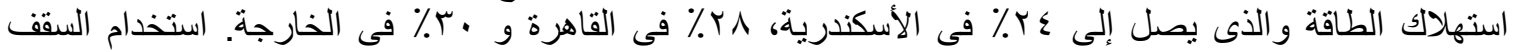

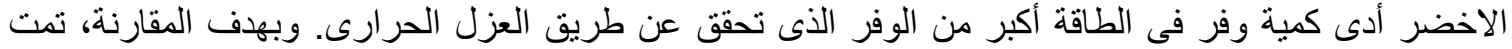

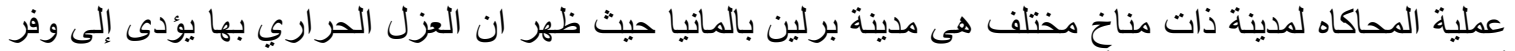

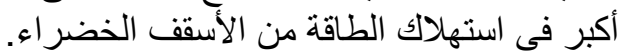
الكلمات المفتاحية: الأسقف الخضر اء، محاكاة استهلاك الطاقة، المبانى السكنية المكيفة. 